\title{
Pengaruh Kepemimpinan Etis dan Iklim Etis terhadap Komitmen Afektif
}

\author{
Anwar Munajah ${ }^{1,2}$, Debora E. Purba² \\ Komisi Pemberantasan Korupsi ${ }^{1}$ \\ Fakultas Psikologi Universitas Indonesia ${ }^{2}$ \\ email: alifwafii@gmail.com
}

\begin{abstract}
Abstrak
Penelitian ini bertujuan untuk melihat efek mediasi iklim etis pada pengaruh kepemimpinan etis dan komitmen afektif pada sebuah lembaga pemerintahan di Indonesia. Data diperoleh dari karyawan tetap dan pegawai negeri sipil yang dikaryakan ( $\mathrm{N}=$ 100), dan dianalisis menggunakan teknik regresi dari macro PROCESS Hayes pada SPSS versi 21. Hasil penelitian menunjukkan persepsi karyawan pada kepemimpinan etis berpengaruh positif dan signifikan pada komitmen afektif karyawan (total effect=0.8387, SE=0.0544, 95\% Cl[0.7307, 0.9468)). Selanjutnya iklim etis berperan sebagai mediator pada hubungan antara kepemimpinan etis dan komitmen afektif (indirect effect=0.1696, SE=0.0406, 95\% Cl[0.1031, 0.2626)). Hal ini menunjukkan bahwa kepemimpinan etis berpengaruh secara tidak langsung pada komitmen afektif lewat iklim etis.
\end{abstract}

Kata Kunci: kepemimpinan etis, iklim etis, komitmen afektif.

\section{The effect of ethical leadership and ethical climate on affective commitment}

\begin{abstract}
This study aims to determine the influence of ethical leadership and ethical climate on affective commitment. Data were taken from employees in a governmental organization, and were analyzed using Hayes' PROCESS macro on SPSS ver. 21. Results showed that perceived ethical leadership positively influenced individual's affective commitnent (total effect $=0.8387$, SE $=0.0544,95 \% \mathrm{Cl}[0.7307,0.9468)$ ). Results also showed that perceived ethical climate mediated the relationship between perceived ethical leadership and affective commitment (indirect effect $=0.1696$, SE $=0.0406$, $95 \% \mathrm{Cl}[0.1031,0.2626))$. Theoretical and practical implications will be discussed.
\end{abstract}

Keyword: ethical leadership, ethical climate, and affective commitment.

\section{Pendahuluan}

Kompetensi merupakan faktor kunci penentu bagi seseorang dalam menghasilkan kinerja yang sangat baik (Kadir, M.A, 2016), namun SDM yang kompeten dan profesional tidak cukup menjamin keberhasilan suatu organisasi mewujudkan misi, visi dan tujuan organisasi. Komitmen yang kuat dari karyawan terhadap organisasi tempat ia bekerja juga dibutuhkan oleh organisasi agar mampu memberikan kontribusi lebih banyak untuk menjaga eksistensi organisasi. Komitmen organisasi menurut Allen dan Meyer (2013) merupakan suatu pola pikir atau keadaan psikologis yang dapat mencerminkan keingi- nan (komitmen afektif), kebutuhan (komitment kontinuans), dan kewajiban (komitmen normatif) karyawan untuk mempertahankan keanggotaannya pada sebuah organisasi. Karyawan dengan komitmen afektif yang kuat akan mengidentifikasikan diri dan terlibat aktif dalam organisasi dan menikmati keanggotannya dalam organisasi. Komitmen kontinuans atau rasional berkaitan dengan komitmen yang didasarkan pada persepsi karyawan atas kerugian yang akan diperolehnya jika ia tidak melanjutkan pekerjaannya dalam organisasi. Oleh karena itu, karyawan yang memiliki komitmen rasional yang kuat akan bertahan dalam organisasi karena mereka membutuhkan (need to). Sementara itu, 
komitmen normatif berkaitan dengan perasaan karyawan terhadap keharusan untuk tetap bertahan dalam organisasi. Oleh karena itu, karyawan yang memiliki komitmen normatif yang tinggi akan bertahan dalam organisasi karena mereka merasa seharusnya melakukan hal tersebut.

Dari ketiga komponen komitmen tersebut di atas, komitmen afektif adalah komponen yang paling sering diteliti karena menunjukkan keterikatan karyawan pada organisasi yang didasarkan pada identifikasinya pada organisasi, sehingga berpengaruh positif pada perilaku positif karyawan, sepertinya keingingan meraih tujuan organisasi, tingginya tingkat perilaku kewargaorganisasian, menurunnya tingkat absensi dan turnover karyawan serta mempengaruhi resistensi karyawan (Rhoades, Eisenberger, \& Ameli, 2001; Kim \& Mauborgne, 1993; Oreg, 2006; Peccei, Giangreco, \& Sebastiano, 2011).

Faktor penyebab dari komitmen afektif dapat dibagi ke dalam tiga kategori: (1) Karakteristik Organisasi, meliputi sistem desentralisasi, adanya kebijakan organisasi yang adil, dan cara menyampaikan kebijakan organisasi kepada individu, dukungan organisasi (McCormick \& Donohue, 2016), konsistensi dan kekuatan iklim (Sanders \& de Reuver, 2008), (2) Karakteristik individu, yaitu gender, usia, lama kerja, status pernikahan dan tingkat pendidikan, dan kepribadian, extraversion dan stabilitas emosi (Steers, 1977; Marsh \& Mannari, 1977; Purba, Oostrom, Van der Molen, \& Born, 2015) (3) Pengalaman Kerja yaitu meliputi desain pekerjaan, hubungan bawahan dengan atasan dan persepsi karyawan pada kepemimpinan etis (Demirtas \& Akdogan, 2015; Hackman \& Oldham, 1975 Neubert, Carlson, Kacmar \& Chonko, 2009).

Penelitian ini akan berfokus pada persepsi karyawan pada kepemimpinan etis sebagai faktor penyebab komitmen afektif, karena pemimpin yang etis merupakan salah satu faktor penting yang mempengaruhi sikap dan karyawan pada lembaga yang sedang diteliti. Persepsi karyawan pada kepemimpinan etis (selanjutnya akan disingkat sebagai kepemimpinan etis) didefinisikan sebagai penampilan perilaku normatif yang tepat me- lalui tindakan pribadi dan hubungan interpersonal dan promosi perilaku tersebut kepada bawahan melalui komunikasi dua arah, penguatan dan pengambilan keputusan (Brown, M. E., Treviño, L. K., \& Harrison, D. A. 2005). Hasil penelitian sebelumnya menemukan bahwa perceived ethical leadership (kepemimpinan etis) memiliki korelasi positif dengan komitmen afektif (Demirtas \& Akdogan, 2015; Den Hartog \& De Hoogh, 2009; Kim et al., 2011; Ruiz-Palomino et al., 2013). Dengan demikian, peneliti berargumentasi bahwa:

Hipotesis 1: Persepsi karyawan pada kepemimpinan etis berpengaruh positif pada komitmen afektif karyawan.

Selanjutnya kepemimpinan etis menunjukkan hubungan signifikan dengan iklim etis (Demirtas \& Akdogan, 2015; Lu, ChinShan \& Lin, Chi-Chang, 2014; Shin, 2011;). Iklim etika organisasi menurut Cullen, Victor \& Stephens (1989) adalah persepsi karyawan mengenai praktik dan prosedur organisasi yang khas yang memiliki konten etika. Iklim etis menggambarkan secara garis besar bagaimana perusahaan secara keseluruhan menghadapi masalah etika, yang erat hubungannya dengan kegiatan pengambilan keputusan. Pada sebuah masyarakat kolektif seperti Indonesia (Hofstede, 1991), pemimpin dianggap sebagai seorang ayah yang merupakan contoh bagi bawahannya. Dalam hal ini, persepsi karyawan pada pemimpin mereka akan sangat mempengaruhi sikap dan perilaku mereka di organisasi (Purba et al., 2015). Dengan demikian, pada sebuah masyarakat kolektif, karyawan akan menganggap organisasinya memiliki iklim etis jika melihat pemimpinnya bertindak etis. Dengan demikian, peneliti berargumentasi bahwa:

Hipotesis 2: Persepsi karyawan pada kepemimpinan etis berpengaruh positif pada iklim etis organisasi.

Penelitian terdahulu menunjukkan bahwa kepemimpinan etis berpengaruh pada komitmen afektif melalui variabel lain, yaitu iklim etis (Demirtas \& Akdogan, 2015; Neubert et al., 2009). Kedua penelitian di atas dilakukan di Turki dan USA yang merupakan masyarakat dengan budaya individualistik (Hofstede, 1991). Penelitian ini merupakan 
replikasi dari kedua penelitian di atas dengan alasan bahwa penelitian serupa belum pernah diteliti di Indonesia yang memiliki budaya kolektif (Hofstede, 1991), dan menganut budaya patriarkal. Peneliti menduga, model penelitian dimana persepsi karyawan pada iklim organisasi yang etis merupakan mediator pada hubungan antara kepemimpinan etis dan komitmen afektif dapat digeneralisasikan di Indonesia, khususnya pada organisasi pemerintah yang menekankan etika sebagai nilai organisasi. Dengan demikian, peneliti berargumentasi bahwa:

Hipotesis 3: Iklim etis berpengaruh positif pada komitmen afektif karyawan.

Hipotesis 4: Iklim etis berperan sebagai mediator pada hubungan antara kepemimpinan etis dan komitmen afektif karyawan.

\section{Metode}

\section{Subjek}

Sampel penelitian ini adalah 100 karyawan yang terdiri dari pegawai tetap maupun pegawai negeri yang di pekerjakan di salah satu kedeputian di Lembaga $X$ yang merupakan salah satu lembaga penegak hukum yang dibentuk pada masa reformasi dan diharapkan menjadi lembaga yang independen, berintegritas, efektif dan efisien dalam melaksanakan tugas-tugasnya. Lembaga $X$ diharapkan menjadi organisasi role model dalam melaksanakan reformasi birokrasi. Status kepegawaian di Lembaga $\mathrm{X}$ terdiri dari Pegawai Tetap (PT), dan Pegawai Negeri Yang Dipekerjakan (PNYD).

Tipe penelitian yang digunakan oleh peneliti menurut penggolongan dari Kumar (2005) adalah applied research, korelasional, dan kuantitatif. Tipe applied research sering digunakan untuk ilmu sosial, yang berarti teknik, prosedur, dan metode penelitiannya diterapkan pada beragam aspek dari situasi, isu, permasalahan, atau fenomena sehingga informasi atau hasil penelitian yang diperoleh dapat diaplikasikan untuk hal-hal seperti contohnya menyusun kebijakan dan meningkatkan pemahaman akan suatu fenomena.
Adapun jenis desain penelitian yang digunakan peneliti dalam penelitian ini berdasarkan jumlah kontak pada populasi penelitian adalah cross-sectional yang berguna untuk mempelajari suatu fenomena dengan pengambilan data yang dilakukan dalam sekali waktu dan diambil kesimpulan berdasarkan hasil data. Apabila dilihat dari jenis periode referensi, penelitian ini menggunakan desain retrospective yaitu mempelajari fenomena, situasi, permasalahan, atau isu yang sudah terjadi di masa sebelumnya (Kumar, 2005). Pada penelitian ini, peneliti ingin mengetahui tingkat persepsi kepemimpinan etis oleh karyawan selama bekerja sehingga dapat diketahui hubungannya terhadap iklim etis dan komitmen afektif. Sedangkan berdasarkan sifat penelitiannya, penelitian ini tergolong non-experimental yaitu penelitian yang dilakukan secara tidak langsung, dan lebih mengarah kepada pengumpulan data dan dalam hal ini peneliti tidak melakukan kontrol atau manipulasi apapun terhadap variabel bebas (Kumar, 2005).

Variabel-variabel yang diteliti adalah kepemimpinan etis, iklim etis dan komitmen afektif yang akan dijelaskan lebih detail sebagai berikut: kepemimpinan etis adalah penampilan perilaku normatif yang tepat melalui tindakan pribadi dan hubungan interpersonal dan promosi perilaku tersebut ke pengikut melalui komunikasi dua arah, penguatan dan pengambilan keputusan (Brown et al., 2005). Iklim etis organisasi adalah persepsi dan penerimaan individu-individu terhadap praktik dan prosedur yang ada dalam organisasi karena etika yang muncul di dalam organisasi akan sangat berpengaruh terhadap perilaku dan pengetahuan individu untuk mencapai kinerja yang baik (Victor \& Cullen ,1987).

\section{Pengukuran}

Data penelitian didapatkan dari kuesioner yang disebarkan kepada responden dengan menggunakan alat ukur untuk masing masing variabel yaitu kuesioner kepemimpinan etis diadaptasi dari Ethical Leadership Questionnaire (ELQ) yang dikembangkan Yukl (2010), kuesioner ini terdiri dari 15 item 
yang dirancang secara komprehensif dengan memperhatikan unsur-unsur kepemimpinan etis yang paling penting, meliputi integritas, kejujuran, keadilan, komunikasi nilai etika, konsistensi perilaku dengan nilai-nilai yang dianut, panduan etis, dan altruisme. Kuesioner iklim etis diadaptasi dari Ethical Climate Quesionaire (ECQ) yang dikembangkan Victor \& Cullen(1986), kuesioner ini dirancang dengan mempertimbangkan 5 dimensi iklim etis yaitu kepedulian, kemandirian, instrumental, hukum dan kode etik serta aturan yang berlaku. Kuesioner komitmen afektif mengambil Affective Commmitment Scale Item yang terdiri dari 8 item dan diadaptasi dari A Three-Component Organizational Commitment Quesionnaire yang dikembangkan oleh Allen \& Meyer (1997).

\section{Analisis data}

Pada penelitian ini, peneliti menggunakan penghitungan statistik dengan menggunakan program SPSS (Statistical Package for the Social Science) versi 2.3. pada tahap awal dilakukan uji reliabilitas dan validitas terhadap alat ukur yang digunakan untuk mengetahui apakah alat ukur tersebut tetap atau tidak. Untuk mengukur reliabilitas instrumen pada penelitian ini, digunakan teknik Alpha Cronbach untuk mengetahui indikatorindikator apa yang harus dihapus atau dihilangkan guna mendapatkan nilai reliabilitas yang baik. Sementara uji validitas dilakukan untuk mengetahui apakah semua pernyataan (instrumen) penelitian yang diajukan untuk mengukur variabel penelitian adalah valid. Adapun hasil uji instrumen sebagai berikut:

Tabel 1. Hasil Uji Reliabilitas dan Validitas

\begin{tabular}{llll}
\hline Variabel & Cronbach's Alpha & Range Validity & N of Items \\
\hline Komitmen Afektif & 0,828 & $0.276-0.717$ & 8 \\
Kepemimpinan Etis & 0,918 & $0.330-0.746$ & 15 \\
Iklim Etis & 0,897 & $0.426-0.720$ & 11 \\
\hline
\end{tabular}

Berdasarkan tabel di atas bisa dilihat bahwa nilai cronbach alpha seluruh variabel berkisar antara 0 sampai 1 , dengan demikian keseluruhan item dalam instrumen pengukuruan dapat di nyatakan reliabel. Dan dari range validity dapat kita lihat bahwa seluruh item pada ketiga variabel berada di antara 0 sampai 1, dengan demikian keseluruhan item dalam instrumen pengukuran dapat dinyatakan valid.

Teknik analisis data selanjutnya adalah:

1) Statistik deskriptif, untuk mendapatkan frekuensi, persentase, mean, skor maksimum, skor minimum, median, dan standard deviation. Tujuannya adalah untuk melihat gambaran data demografis responden dan gambaran responden secara umum terhadap variabel-variabel yang diukur.

2) Analisis korelasi Pearson (Pearson's correlation), yang digunakan untuk melihat hubungan antar variabel.

Macro PROCESS pada SPSS dari Hayes, yang digunakan untuk uji efek mediasi dari komitmen afektif pada hubungan antara POS dan intensi turnover. Menurut Hayes (2012), proses ini menyediakan beragam tipe untuk mengukur besaran pengaruh (effect size) dari pengaruh tidak langsung (indirect effect) dan juga dapat menyimpulkannya melalui interval bootstrap confidence. Preacher dan Hayes (2004) mengatakan bahwa teknik bootstrap merupakan pendekatan nonparametrik untuk memperkirakan ukuran suatu efek atau pengaruh dan pengujian hipotesis yang mengabaikan asumsi tentang ukuran distribusi variabel atau sampling statistik. Macro PROCESS ini memiliki keunggulan karena teknik bootstrapping yang ada dapat memperkirakan standard error dengan $95 \%$ dan $99 \%$ confidence interval di suatu populasi dan dapat melakukan sampling with replacement dari sejumlah besar sampel dan menghitung pengaruh tidak langsung antar variabel (Preacher \& Hayes, 2004). 


\section{Hasil}

Dari 100 responden didapatkan hasil penelitian dengan data demografis sebagai berikut:

1. Jenis kelamin responden dapat diketahui bahwa responden laki-laki lebih banyak (82\%) dibandingkan dengan jumlah responden perempuan (18\%).

2. Usia responden sebagian besar berada dalam rentang usia 31 - 40 tahun (66\%), sementara urutan kedua berada diusia lebih dari 41 tahun yaitu sebesar (18\%), dan diusia antara 21 - 30 tahun sebesar $(16 \%)$.
3. Status kepegawaian, sebagian besar responden dalah berstatus Pegawai Tetap (PT) sebesar $(79 \%)$, sementara sisanya adalah Pegawai Negeri Yang Dipekerjakan (PNYD) sebesar (21\%).

4. Jabatan responden sebagian besar fungsional sebesar $(73 \%)$ dan sisanya adalah staf sebesar $(27 \%)$.

5. Lama bekerja responden dapat diketahui bahwa sebagian besar responden sudah bekerja di atas 5 tahun (65\%), dan pada lama bekerja antara 3 - 5 tahun sebesar $(16 \%)$, antara $1-3$ tahun sebesar $(16 \%)$ dan sisanya bekerja kurang dari 1 tahun sebesar $(13 \%)$.

\section{Tabel 2. Hasil Analisis Kepemimpinan Etis, Iklim Etis, Komitmen Afektif dan Data Demografis}

\begin{tabular}{lllllllllll}
\hline Variabel & Mean & SD & $\mathbf{1}$ & $\mathbf{2}$ & $\mathbf{3}$ & $\mathbf{4}$ & $\mathbf{5}$ & $\mathbf{6}$ & $\mathbf{7}$ & $\mathbf{8}$ \\
\hline 1. Jenis Kelamin & 1 & .39 & 1 & & & & & & & \\
2. Usia & 2.02 & .59 & $-.24^{*}$ & 1 & & & & & & \\
3. Lama Bekerja & 3.43 & .87 & $-.29^{* *}$ & $.70^{* *}$ & 1 & & & & & \\
4. Jabatan & 1.73 & .45 & -.18 & $.48^{* *}$ & $.69^{* *}$ & 1 & & & & \\
5. Status Kepegawaian & 1.21 & .41 & $-.24^{*}$ & .07 & .08 & $.31^{* *}$ & 1 & & & \\
6. Kepemimpinan etis & 3.57 & .79 & $.27^{* *}$ & -.07 & .00 & -.01 & -.11 & 1 & & \\
7. Iklim etis & 3.53 & .78 & $.27^{* *}$ & -.03 & .02 & .00 & -.11 & $.62^{* *}$ & 1 & \\
8. Komitmen afektif & 3.50 & .78 & $.27^{* *}$ & -.06 & -.03 & -.03 & -.03 & $.85^{* *}$ & $.71^{* *}$ & 1 \\
\hline
\end{tabular}

${ }^{*} . p<0.05$ (2-tailed). ${ }^{* *} . p<0.01$ (2-tailed). Note jenkel 1=laki $2=$ perempuan

Catatan. Jenis kelamin di-dummycode ( 1 = laki-laki, $2=$ perempuan). Usia di-dummycode $(1$ = 20-30 tahun, $2=30-40$ tahun, $3=$ di atas 40 tahun). Lama kerja di-dummycode $(1=$ kurang dari 1 tahun, 2 = 1-3 tahun, $3=3-5$ tahun, $4=$ di atas 5 tahun). Jabatan di-dummycode $(1=$ fungsional, 2 = staff). Status kepegawaian di-dummycode $(1=$ pegawai tetap, 2 = pegawai negeri yang dipekerjakan).

Berdasarkan data diatas, diperoleh hasil bahwa kepemiminan etis memiliki hubungan positif dengan komitmen afektif $(r=0.85, p<0.01)$, ini membuktikan bahwa $\mathrm{H} 1$ yang menyatakan bahwa terdapat hubungan antara kepemimpinan etis dan komitmen afektif di lembaga $X$ terbukti dengan hubungan yag bersifat positif, dengan kata lain bahwa semakin tinggi tingkat kepemimpinan etis di lembaga $\mathrm{X}$ maka akan semakin meningkatkan komitmen afektif di lembaga tersebut.

Sementara data diatas menunjukkan hasil bahwa kepemimpinan etis memiliki hubungan positif dengan iklim etis $(r=0.62$, $\mathrm{p}<0.01$ ). Ini membuktikan bahwa $\mathrm{H} 2$ yang menyatakan bahwa terdapat hubungan antara kepemimpinan etis dan iklim etis pada lembaga $X$ terbukti dengan hubungan yang bersifat positif, dengan kata lain semakin tinggi tingkat kepemimpinan etis di lembaga $X$ maka akan semakin meningkatkan iklim etis dilembaga tersebut.

Selain itu juga didapatkan hasil bahwa iklim etis berhubungan dengan komitemen afektif $(r=0.72, p<0.01)$. Hal ini pun membuktikan $\mathrm{H} 3$ yang menyatakan bahwa terda- 
pat hubungan antara iklim etis dan komitmen afektif pada lembaga $X$ dengan hubungan yang bersifat positif. Ini menunjukkan bahwa semakin tinggi tingkat iklim etis maka akan juga meningkatkan tingkat komitmen afektif dilembaga tersebut.

Dan dari hasil data tersebut bahwa hubungan antara kepemimpinan etis dengan komitmen afektif baik dengan maupun tanpa iklim etis sebagai mediator, tetap memiliki hubungan positif. Dengan kata lain H4 yang menyatakan bahwa iklim etis sebagai mediator antara kepemimpinan etis dengan komitmen afektif adalah benar, walaupun tetap ada hubungan positif antara kepemimpinan etis dengan komitmen afektif secara langsung.

Berdasarkan data demografis, diketahui bahwa hanya variabel jenis kelamin yang terbukti memiliki hubungan yang signifikan dengan komitmen afektif $(r=0.27, p<0.05)$, dapat dilihat laki-laki cenderung lebih punya komitmen afektif yang tinggi.

Tabel 3. Hasil Analisis Pengaruh Kepemimpinan Etisi, Iklim Etis Komitmen Afektif.

\begin{tabular}{lllllll}
\hline & Effect & SE & T & P & LLCI & ULCI \\
\hline Total Effect & .8387 & .0544 & 15.4147 & .0000 & .7307 & .9468 \\
Direct Effect & .6691 & .0600 & 11.1471 & .0000 & .5499 & .7883 \\
Indirect Effect & .1696 & .0406 & & & .1031 & .2626 \\
\hline
\end{tabular}

*) Signifikan pada LOS 95.00, $p<0.05$

Berdasarkan tabel di atas, pengaruh langsung kepemimpinan etis terhadap komitmen afektif sangat signifikan tertera pada (total effect $=.8387, \mathrm{SE}=.0544,95 \% \mathrm{Cl}[.7307$, .9468]), signifikasi ini nampak pada LLCl dan ULCI yang tidak ada nilai negatif (tidak melewati 0). Direct effect adalah menunjukkan hubungan pengaruh antara kepemimpinan etis dan komitmen afektif setelah masuknya variabel iklim etis ke dalam model sebagai mediator, dan dari tabel menunjukkan penurunan angka menjadi (direct effect $=.6691$, $\mathrm{SE}=.0600,95 \% \mathrm{Cl}[.5499, .7883])$, yang artinya iklim etis memiliki pengaruh dalam hubungan kepemimpinan etis dan komitmen afektif, maka iklim etis dipertimbangkan sebagai variable mediator. Dan pengaruh tidak langsung iklim etis sebagai mediator tertulis (indirect effect) adalah (indirect effect $=.1696$, $\mathrm{SE}=.0406,95 \% \mathrm{Cl}[.1031, .2626]) . \mathrm{Hal}$ ini menunjukan bahwa $\mathrm{H} 4$ yang menyatakan bahwa terdapat peran iklim etis sebagai mediator pada hubungan antara kepemimpinan etis dan komitmen afektf di lembaga $\mathrm{X}$ terbukti dalam penelitian ini.

Dengan kecilnya pengaruh tidak langsung yang tertera di indirect effect iklim etis juga bisa disebut sebagai partial mediator, dan dengan adanya pengaruh signifikan dari kepemimimpinan etis terhadap komitmen afektif, maka rancangan intervensi yang akan disusun lebih ditujukan untuk meningkatkan kepemimpinan etis pada semua lini manager agar terbentuk peningkatan iklim etis di kalangan pegawai sehingga akan mempengaruhi komitmen afektif karyawan yang akan meningkat.

\section{Pembahasan}

Berdasarkan hasil analisis data korelasi dan pengaruh diatas dapat dilihat bahwa variabel kepemimpinan etis berhubungan positif dan berpengaruh signifikan terhadap komitmen afektif, ini menunjukkan hipotesis pertama terbukti. Untuk hipotesis kedua yaitu variabel kepemimpinan etis dengan iklim etis juga menunjukkan adanya hubungan positif dan pengaruh yang signifikan. Hipotesis ketiga terbukti dengan adanya hasil iklim etis menunjukkan hubungan positif dan pengaruh yang signifikan terhadap komitmen afektif. Dan dalam hubungan pengaruh antara kepemimpinan etis dengan komitmen afektif dapat diketahui bahwa iklim etis berperan menjadi variabel mediator. Hasil penelitian ini 
sejalan dengan penelitian sebelumnya yang menemukan bahwa perceived ethical leadership (kepemimpinan etis) memiliki korelasi positif dengan komitmen afektif (Demirtas dan Akdogan, 2015; Ruiz-Palomino et al., 2013; Kim et al., 2011; Den Hartog and De Hoogh, 2009). Selanjutnya kepemimpinan etis menunjukkan hubungan signifikan dengan iklim etis (Shin, Y., 2012; Demirtas \& Akdogan, 2015; Lu, Chin-Shan \& Lin, Chi-Chang, 2014). Sementara iklim etis menunjukkan hubungan yang signifikan terhadap komitmen afektif dan peran iklim etis sebagai mediator antara kepemimpinan etis dengan komitmen afektif (Demirtas \& Akdogan, 2015; Cemberci et al., 2016). Artinya perilaku etis yang ditampilkan oleh seorang pemimpin akan memberikan pengaruh pada pengembangan moral karyawan dan diharapkan akan menciptakan suatu ikatan emosional yang kuat antara karyawan dengan organsasi tempatnya bekerja. Hubungan antara kepemimpinan etis menunjukkan pengaruh positif dan signifikan terhadap komitmen afektif, dan melalui mediator iklim etis juga terdapat pengaruh positif dan signifikan antara kepemimpinan etis dan komitmen afektif.

Dari hasil penelitian ini serta penelitian sebelumnya menunjukkan bahwa kepemimpinan etis merupakan prediktor dari komitmen afektif sebagai prediktor, Kepemimpinan etis menjadi faktor yang penting dalam bidang perilaku organisasi. Dengan meningkatkan persepsi kepemimpinan etis dari karyawan akan mampu membantu organisasi untuk mengatur dan membangun sebuah kerangka iklim etis dalam lingkungan kerja mereka semakin kuat yang pada akhirnya akan akan mempengaruhi komitmen afektif karyawan. Peneliti berpendapat perlu adanya rancangan intervensi yang tepat untuk permasalahan organisasi ditujukan untuk meningkatkan kepemimpinan etis dan iklim etis bagi semua lini manajer melalui peningkatan komunikasi dan teamwork sehingga diharapkan akan berdampak pada peningkatan komitmen organisasi lembaga $X$. Berdasarkan hasil analisis data sehubungan dengan persepsi kepemimpinan etis dan iklim organisasi ini didapatkan informasi bahwa kepemimpinan etis dan iklim etis di organisasi ini sudah dirasakan oleh karyawan namun belum dikomunikasikan secara baik oleh pemimpin kepada karyawan sehingga kepemimpinan etis dan iklim etis yang baik tidak membuat komitmen karyawan menjadi meningkat. Selain itu dalam tahap seleksi dan rekrutmen karyawa di Lembaga $X$ yang telah dinyatakan lulus, sebelumnya telah dilakukan serangkaian seleksi ketat dengan ujian tertulis, asesmen dan melakukan penelusuran profil calon karyawan serta selanjutnya dilakukan wawancara untuk mengetahui standar integritasnya, bahkan untuk manajer puncak dilakukan fit and proper oleh lembaga negara lain. Ini artinya pada setiap manajer telah memiliki standar etika tertentu namun masih ditemukan adanya bias persepsi etis saat menerapkannya di Lembaga $X$ yang telah memiliki iklim etis yang telah ada dan berlaku selama ini.

Sesuai dengan yang disampaikan oleh Shanock dan Eisenberger (2006), bahwa atasan yang bertindak sebagai perwakilan organisasi yang bertanggung jawab untuk mengarahkan, mengevaluasi dan membina bawahan, memainkan peran kunci dalam melihat bahwa tujuan dan sasaran dari manajemen telah diterapkan secara efektif. Seorang atasan telah terbukti dapat membangun organisasi melalui persepsi dukungan organisasi mereka sendiri dengan melakukan pekerjaan mereka dengan lebih efektif, termasuk dengan lebih mendukung bawahannya. Maka bawahan yang merasa didukung oleh atasan akan memperlihatkan peningkatan komitmen organisasi dan terlibat dengan perilaku sukarela dalam membantu organisasi. Oleh karena itu, membina para atasan dengan baik akan meningkatkan iklim organisasi, dan yang terpenting adalah bahwa hal ini dapat berpengaruh kepada komitmen organisasi bawahan. Studi yang dilakukan oleh Kim, HyoSook (2007) menunjukkan bahwa konteks organisasi seperti internal komunikasi dapat mempengaruhi persepsi karyawan terhadap komitmen organisasi. Komunikasi internal membentuk konteks organisasi yang sering mempengaruhi penilaian keadilan, komitmen, kepercayaan, kontrol mutualitas, kepuasan kerja, dan komunikasi dalam hubungan kar- 
yawan tersebut dapat menjadikan hasil yang terkait erat dengan keadilan organisasi

\section{Kesimpulan}

Berdasarkan hasil penelitian dan pembahasan yang telah dilakukan, dapat diambil kesimpulan bahwa kepemimpinan etis terbukti berpengaruh positif dan signifikan terhadap komitmen afektif; kepemimpinan etis terbukti berpengaruh positif dan signifikan terhadap iklim etis; iklim etis berpengaruh positif dan signifikan terhadap komitmen afektif; iklim etis terbukti sebagai variabel mediator antara kepemimpinan etis dan komitmen afektif.

Beberapa saran yang dapat diberikan terkait dengan penelitian ini yaitu persepsi karyawan atas kepemimpinan etis menjadi hal yang cukup penting untuk membentuk iklim etis dalam organisasi yang pada akhirnya diharapkan meningkatkan komitmen afektif karyawan terhadap organisasinya, sehingga sikap dan perilaku pimpinan yang mendasarkan pada norma etis dalam setiap pengambilan keputusan perlu mendapatkan perhatian dalam interaksi dan komunikasi dengan karyawan. Komitmen organisasi merupakan investasi yang berharga pada organisasi sehingga penelitian ini juga bisa dikembangkan pada komitmen yang lain yaitu komitmen kontinuans dan komitmen normatif. Penelitian diharapkan bisa dilaksanakan secara berkala dengan jumlah sampel lebih banyak dengan komposisi yang seimbang antara Pegawai Tetap dengan Pegawai Negeri Yang Dipekerjakan, serta dilakukan dengan menghilangkan bias penelitian akibat pengaruh atasan serta kondisi tertentu dalam organisasi.

\section{Daftar Pustaka}

Allen and Meyer. (2013). The measurement and antecedents of affective, contintinuance and normative commitment to organitazion. PT Elex Media Komputindo, Jakarta.

Allen, N. J. \& J. P. Meyer. (1997). Commitment in The Workplace Theory Research and Application. California: Sage Publications
Brown, M. E., Treviño, L. K., \& Harrison, D. A. (2005). Ethical leadership: A social learning perspective for construct development and testing. Organizational Behavior and Human Decision Processes, 97: 117-34

Cambersi, M., Civelek, M.E., \& Gunel, D., (2016) The mediator effect of ethical climate on the relation between ethical leadership and organizational commitment. Siyaset, Ekonomi ve Yönetim Araştırmaları Dergisi, 2016, Yıl:4, Cilt:4, Sayı:1

Cullen, J.B., Victor, B., Stephens, C., (1989). An ethical weather

report: Assesing the organization's ethical climate. Organizational Dynamics, 18: $50-63$.

Demirtas, O., \& Akdogan, A.A., (2015). The effect of ethical leadership behavior on ethical climate, turnover intention, and affective commitment. Journal of Business Ethics. 130, 59-67.

Den Hartog, D. N., \& De Hoogh, A. H. B. (2009). Empowerment and leader fairness and integrity: Studying ethical leader behavior from a levelsof-analysis perspective. European Journal of Work and Organizational Psychology, 18(2), 199-230.

Franke, R. H., Hofstede, G., \& Bond, M. H. (1991). Cultural roots of economic performance: A research notea. Strategic management journal, 12 (S1), 165-173.

Hackman, J.R., and Oldham. G.R., (1975). Development of the job diagnostic survey. Journal of Applied Psychology, 60.

Kadir, Muh Akob, (2016), SDM dan Daya Saing dalam Bingkai Kearifan Lokal, Alauddin University Press.

Kim, Hyo-Sook. (2004). "Organizational Structure and Internal Communication as Antecedents of EmployeeOrganization Relationships: A Multilevel Analysis".Journal of International Communication Association. Sheraton New York, New York City, NY. 2009-05-25. 
Kim, W.C. and Mauborgne, R. (1993). Procedural justice, attitudes and subsidiary top management compliance with multinationals' corporate strategic decisions. Academy of Management Journal, 36 (3). 502-526

Kim, W.G. dan Brymer, R.A. (2011), "The effects of ethical leadership on manager job satisfaction, commitment, behavioral outcomes, and firm performance", International Journal of Hospitality Management, Vol. 30, pp. 1020- 1026

Kumar, Ranjit. 2005. Research Methodology: a step by step guide for beginners. Londong: sage

Lu, C-S. dan Lin, C-C. (2014), "The Effects of Ethical Leadership and Ethical Climate on Employee Ethical Behavior in the International Port Context", Journal of Business Ethics, Vol. 124, pp. 209-223.

Marsh, R. M., \& Mannari, H. (1977). Organizational commitment and turnover: A prediction study. Administrative Science Quarterly, 5775.

McCormick, L., \& Donohue, R., (2016), Antecedents of affective and normative commitment of organisational volunteers. The International Journal of Human Recources Mangement.

Meyer, J. P., \& Allen, N. J. (1997). Commitment in the workplace: Theory, research, and application. Thousand Oaks, CA: Sage Publications.

Neubert, M. J., Carlson, D. S., Kacmar, K. M., Roberts, J. A., dan Chonko, L. B. (2009). The virtuous influence of ethical leadership behavior: Evidence from the field. Journal of Business Ethics, 90, 157-170.

Oreg, S. (2006). Personality, context, and resistance to organizational change. European Journal of Work and Organizational Psychology, 15 (1)
Peccei, R., Giangreco, A., \& Sebastiano, A. (2011). The role of organisational commitment in the analysis of resistance to change: Co-predictor and moderator effects. Personnel Review, 40(2), 185-204

Preacher, K.J., \& Hayes, A.F. (2004). SPSS and SAS procedures for estimating indirect effects in simple mediation models. Behavior Research Methods, Instruments, and Computers Vol 36, 717-731. doi: 10.3758/BF03206553

Purba, D. E., Oostrom, J. K., Van der Molen, H. T. \& Born, M. Ph., (2015). Personality and organizational citizenship behavior in Indonesia: The mediating effect of affective commitment. Asian Business \& Management, 14, 2.

Rhoades, L. Eisenberger, R. \& Ameli, S. (2001). Affective Commitment to the Organization: The contribution of Perceived Organizational Support. Journal of Applied Psychology, 86 (5).

Ruiz-Palomino, P., Martinez-Canas, R. dan Fontrodona, J. (2013), "Ethical Culture and Employee Outcomes: The Mediating Role of PersonOrganization Fit", Journal of Business Ethics, Vol. 116, pp. 173-188.

Sanders, K., Dorenbosch, L., de Reuver, R., (2008) "The impact of individual and shared employee perceptions of HRM on affective commitment: Considering climate strength", Personnel Review, Vol. 37 Issue: 4, pp.412-425.

Shanock, L.R. dan Eisenberger, R. (2006). When Supervisors Feel Supportet: Relationships With Subordinates perceived Supervisor Support, Perceived Organizational Support, and Performance. Journal of Applied Psychology, 93 (3): 689-695

Shin, Yuhyung., (2011). CEO Ethical Leadership, Ethical Climate, Climate Strength, and Collective Organizational Citizenship Behavior. Springer Science+Business Media B.V. 
Steers, R. M. (1977). Antecedents and outcomes of organizational commitment. Administrative science quarterly, 46-56.

Victor, B. \& J. B. Cullen. (1987). A Theory And Measure Of Ethical Climate In Organizations In W. C. Frederick.
Research in Corporate Social Performance, JAI Press, Greenwich, CT, Pp. 51- 71

Yukl, Gary, (2010), Kepemimpinan dalam Organisasi, Edisi Kelima. Jakarta: PT. Indeks. 